\title{
World No Tobacco Day: Tobacco is a Threat to the One Health and Sustainability
}

\author{
Dia Mundial Sem Tabaco: O Tabaco é uma Ameaça à Saúde \\ e à Sustentabilidade
}

Subhash Janardhan Bhore (https://orcid.org/0000-0002-4894-2422) ${ }^{1}$

${ }^{1}$ Department of

Biotechnology, Faculty of Applied Sciences, AIMST

University, Bedong-

Semeling Road, 08100,

Semeling, Kedah Darul

Aman Malaysia.subhash@

aimst.edu.my

\begin{abstract}
On 31 st May of every year, in honour of the 'World No Tobacco Day (WNTD),' the international community does organise various events and encourages avoiding all forms of Tobacco consumption. To commemorate WNTD2018, the World Health Organization (WHO) has promoted awareness to highlight the link between Tobacco and cardiovascular disease (CVD). Because, Tobacco use is the second leading cause of CVD, after high blood pressure. In addition to CVD, Tobacco use is also known to cause many non-communicable diseases, including chronic obstructive pulmonary disease (COPD), lung cancer and other complicated disorders caused by smoking. In fact, non-communicable diseases are now emerging as the primary disease burden. Globally, Tobacco use kills about 7 million people each year, and if the trend remains the same, then it will kill more than 8 million people per year by 2030. On the contrary, despite promoting awareness, the Tobacco industry is growing with little or no regulation. However, in the long run, the global community will not be able to afford business as usual as Tobacco has a direct impact on human health, environmental health and sustainable development.

Key words Cancer, Cardiovascular disease, Food supply, Non-communicable diseases, World Health Organization
\end{abstract}

Resumo No dia 31 de maio de cada ano, em homenagem ao Dia Mundial Sem Tabaco (WNTD), a comunidade internacional organiza vários eventos e incentiva a evitar todas as formas de consumo de tabaco. Para comemorar o WNTD-2018, a Organização Mundial da Saúde (OMS) promoveu a conscientização para destacar a ligação entre o tabaco e as doenças cardiovasculares (DCV). Porque, o uso do tabaco é a segunda principal causa de DCV, após a hipertensão arterial. Além do DCV, o uso de tabaco também é conhecido por causar muitas doenças não transmissiveis, incluindo doença pulmonar obstrutiva crônica (DPOC), câncer de pulmão e outros transtornos complicados. De fato, as doenças não transmissíveis estão emergindo como a carga primária da doença. Globalmente, o consumo de tabaco mata cerca de 7 milhões de pessoas a cada ano, e se a tendência permanecer a mesma, matará mais de 8 milhões de pessoas por ano até 2030. Pelo contrário, apesar de promover a conscientização, a indústria do tabaco está crescendo com pouco ou sem regulamentação. No entanto, a longo prazo, a comunidade global não poderá se dar bem, pois o tabaco tem um impacto direto na saúde humana, na saúde ambiental e no desenvolvimento sustentável.

Palavras-chave Câncer, Doença cardiovascular, Suprimento de comida, Doenças não comunicáveis, Organização Mundial da Saúde 


\section{Introduction}

The implementation of the sustainable development goals (SDGs) plan adopted by the United Nations (UN) member states began in January 2016. To achieve the SDGs, UN and stakeholders are leaving no stone unturned. The main aim of the SDGs is to promote 'public health and development' and 'global sustainability' to end poverty, protect the planet and ensure that all people enjoy peace and prosperity ${ }^{1,2}$. The SDG-3 is 'good health and well-being' of people and aimed to ensure the healthy lives and promote well-being for all at all ages. Minimization of the non-communicable and communicable diseases burden is one of the approaches to achieve SDG-3 to boost the global public health. If we work prudently to deal with the disease burden caused by Tobacco and its products, then we will be able to save the millions of lives across the globe, and it can significantly help in achieving SDG-3 and other goals too.

It is estimated that Tobacco is going to kill 1000 million people in $21^{\text {st }}$ century ${ }^{3}$. If we, the global community takes urgent action, then Millions of deaths can be prevented. In this line, the WHO had established the Tobacco Free Initiative (TFI) in 1998. The mission of the WHO TFI's is to reduce the global burden of disease and death caused by Tobacco, thereby protecting present and future generations from the devastating health, social, environmental and economic consequences of Tobacco use and exposure to Tobacco smoke. The TFI specifically focuses the international attention, resources and action on the global Tobacco epidemic.

Recognising the severe impact of non-communicable diseases caused by Tobacco, the WHO Framework Convention on Tobacco Control created and used the MPOWER approach ${ }^{3,4}$. The MPOWER strategy is intended to guide the UNs member states - to effectively monitor Tobacco use, protect people from Tobacco smoke, offer help to quit Tobacco use, warn about the dangers of Tobacco, enforcing bans on Tobacco advertising and promotion, and to raise taxes on Tobacco products $^{4,5}$. This strategy is found useful; however, it is appearing that achieving the goals by 2025 as part of the 2013 WHO Framework Convention on Tobacco is hard ${ }^{6}$. The offline and online media, as well as non-governmental organizations (NGOs) across the globe, are highlighting the gravity of the consequences of Tobacco use. However, the Tobacco industry is growing with little or no regulation. Hence, it seems that a lot more needs to be done to minimize or eliminate the Tobacco threat. Therefore, the global community should come up with additional strategies to deal with the challenges posed by Tobacco.

Globally, Tobacco use kills the massive number of people each year, which is nearly equivalent to the whole population of Bulgaria. If the trend remains the same, Tobacco use will kill more than 8 million people per year by $2030^{7}$. The general notion among people is that Tobacco is only harmful to human health. However, Tobacco use is not only damaging human health but also damages the environmental health as its cultivation, processing, and products distribution cause an enormous adverse impact on the environment. In other words, Tobacco use does have a substantial adverse effect on health. 'One Health' is a term used to point out the aggregate optimal health of people, animals, and the environment ${ }^{8}$. One health is vital for the normal functioning of the global ecosystem and sustainable global development.

Both, directly and indirectly, Tobacco use is causing social, economic, and environmental damages ${ }^{9}$. As a result, it impedes sustainable development. As an effort of supporting the international agenda of the sustainable development, if we impose the most stringent regulations on Tobacco supply and use, then indeed it will boost the 'One Health'. Subsequently, it will enhance the sustainable development (Figure 1).

If we abolish the impact of Tobacco, then it will boost the success of SDG-3 (ensuring healthy lives and the well-being of people) as well as other SDGs as all 17 SDGs are interconnected and interdependent ${ }^{2}$. For instance, 4.3 million hectares of agricultural land used for Tobacco cultivation $^{4}$ could be made available for the cultivation of other food crops to fill in the gaps in the global-food-supply-chain ${ }^{10}$. It will enable accomplishment of SDG-2 - end hunger, achieve food security, improve nutrition and promote sustainable agriculture ${ }^{1,2}$. Simultaneously, this approach will also help to minimize the deforestation for additional agricultural land. As reported by Novotny et al., the deforestation for Tobacco cultivation has increased many serious environmental problems such as water pollution, loss of biodiversity, soil erosion and degradation, and atmospheric carbon dioxide increase ${ }^{11}$. If deforestation is minimized, then it will have a positive impact on 'One Health.'

Bearing in mind the consequences of Tobacco use on human (Chart 1), environmental health, and its negative impact on the sustain- 


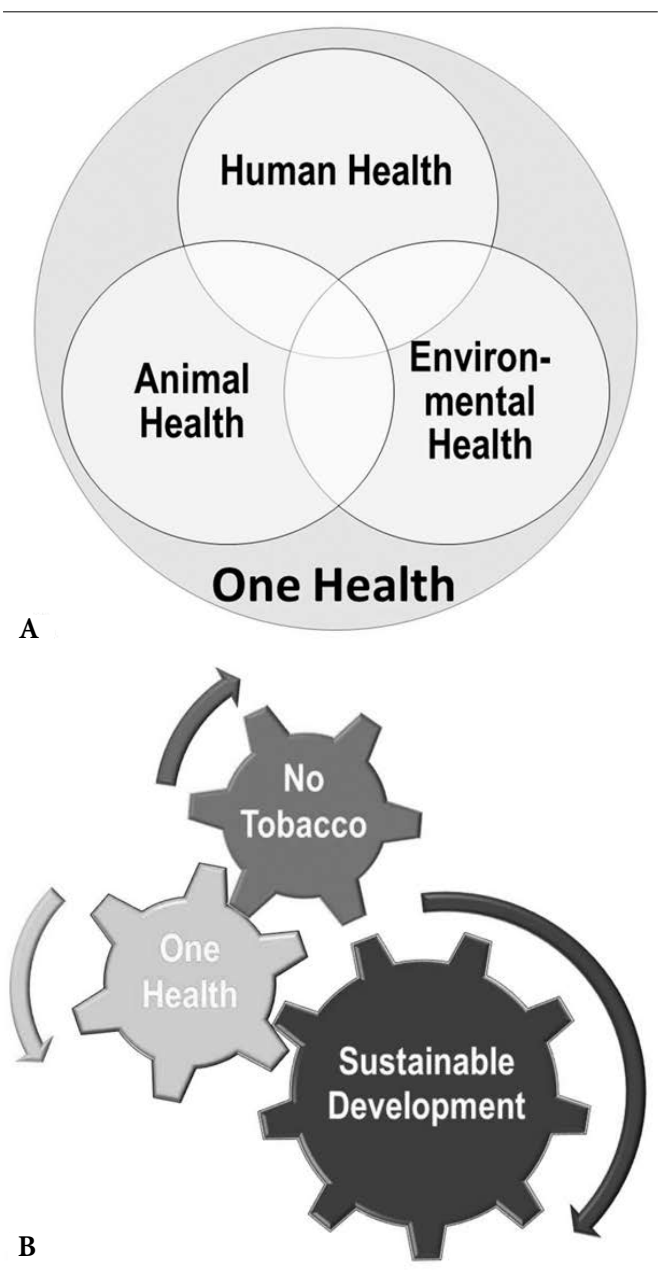

Figure 1. A) The health of humans, animals, and the environment are intimately connected. B) The most stringent restrictions (or ban) on Tobacco supply and use (No Tobacco) will serve as a gear to improve 'One Health' and to promote global sustainable development.

able development ${ }^{7,9,11-13}$, the global community needs to explore the possibility of applying the most stringent regulations on Tobacco supply and use. If the global situation warrants, then we, the global community, should have the courage to ban Tobacco cultivation.

In summary, to achieve SDGs, the global community needs to focus on long term goals, and if necessary, the awkward and unpleasant decisions should be made. Taking into consider- ation the adverse effects of Tobacco on human health, environmental health and global sustainable development at large, a question arises why don't we explore the possibility of imposing the most stringent regulations on Tobacco to support the sustainable development goals adopted by the UNs? To answer this globally important question, we need to trigger healthy discussion. The global community, policymakers, and stakeholders need to have a constructive dialogue to find a suitable solution for the minimization of the adverse effects of Tobacco ${ }^{14}$. We also need to bear in mind that the extraordinary cooperation will be required among policymakers, Tobacco industry stakeholders, international organizations, scientists, and the public to deal with Tobacco menace. The cooperation among all stakeholders will help in accurate Tobacco risk assessment, to come up with robust mitigation measures, and to evaluate the performance of mitigation measures. As a result, meaningful cooperation among all stakeholders will help to solve the smoking and Tobacco-associated problems. To boost the one health and sustainability, a strong determination is essential to deal with the challenges posed by Tobacco. To succeed in a real sense, we need to "Make Every Day World No Tobacco Day" as promoted by the WHO to commemorate the 'World No Tobacco Day'. However, for a Tobacco-free world, as per Johann Wolfgang von Goethe's quote, we need to bear in mind that "Knowing is not enough; we must apply". "Willing is not enough; we must do".

\section{Disclaimer}

The content reflects the views of the author and not the points of view of the author's employer. In part, the content of this article was presented to commemorate the "World No Tobacco Day 2018 ' at AIMST University, Malaysia. 
Chart 1. A list of important facts about Tobacco use and its consequences ${ }^{7,9,12,13}$.

\begin{tabular}{|l|l|}
\hline No & \multicolumn{1}{|c|}{ Fact / Consequence } \\
\hline 1. & Tobacco and its products use kill more than 7 million people every year. \\
\hline 2. & More than 6 million out of 7 million deaths are the result of direct Tobacco use, including smoking. \\
\hline 3. & Over 890,000 people die each year because of exposure to second-hand smoke. \\
\hline 4. & Smoking leads to disease and disability and harms nearly every organ of the human body. \\
\hline 5. & Smoking is the leading cause of preventable deaths. \\
\hline 6. & The Tobacco industry spends billions of dollars every year on cigarette advertising and promotions. \\
\hline 7. & $\begin{array}{l}\text { Smoking causes cancer, heart disease, stroke, lung diseases, diabetes, and chronic obstructive pulmonary } \\
\text { disease (COPD), which includes emphysema and chronic bronchitis. }\end{array}$ \\
\hline 8. & Smoking is a known cause of erectile dysfunction in males. \\
\hline 9. & On average, smokers die ten years earlier than non-smokers. \\
\hline 10. & Thousands of young people start smoking cigarettes every day. \\
\hline 11. & Nearly $80 \%$ of the world's (more than 1 billion) smokers live in low- and middle-income countries. \\
\hline 12. & Only 30 countries meet the best practice for pictorial warnings about Tobacco products. \\
\hline 13. & Only $16 \%$ of the world's population is protected by comprehensive national smoke-free laws. \\
\hline 14. & 80-90\% of preventable cancers of the neck, head, and throat are Tobacco-related. \\
\hline 15. & Tobacco is commercially cultivated in over 125 countries. \\
\hline 16. & $\begin{array}{l}\text { Tobacco users who die prematurely deprive their families of income, raise the cost of healthcare and } \\
\text { hinder sustainable (and economic) development. }\end{array}$ \\
\hline
\end{tabular}

\section{References}

1. Editorial. Towards 2030: Counting and accountability matter. Lancet 2015; 386(10001):1312.

2. Bhore SJ. Global goals and global sustainability. Int. J. Environ. Res. Public Health 2016; 13(10):991.

3. Frieden TR, Bloomberg MR. How to prevent 100 million deaths from tobacco. Lancet 2007; 369(9574):1758-1761.

4. World Health Organization (WHO). Tobacco Free Initiative (TFI). 2018. [cited 2018 May 15]. Available from: http://www.who.int/tobacco/en/

5. World Health Organization (WHO). WHO report on the global tobacco epidemic. 2008. [cited 2018 May 15]. Available from: http://www.who.int/tobacco/mpower/mpower_report_six_policies_2008.pdf

6. Editorial. Nicotine addiction, reduction, and smoking cessation. Lancet 2017; 390(10096):716.

7. World Health Organization (WHO). WHO media centre. Tobacco fact sheet 2018. [cited 2018 May 15]. Available from: http://www.who.int/mediacentre/ factsheets/fs339/en/

8. Stadtländer CTK-H. One health: people, animals, and the environment. Infect Ecol Epidemiol. 2015; 5:30514.

9. World Health Organization (WHO). Tobacco and its environmental impact: an overview Geneva: WHO; 2017. [cited 2018 May 15]. Available at: http://www. who.int/tobacco/publications/environmental-impact-overview/en/

10. Smith BG. Developing sustainable food supply chains. Philos. Trans. R. Soc. Lond. B Biol. Sci. 2008; 363(1492):849-861.
11. Novotny TE, Bialous SA, Burt L, Curtis C, Costa VL, Iqtidar SU, Liu Y, Pujari S, Tursan d'Espaignet E. The environmental and health impacts of tobacco agriculture, cigarette manufacture and consumption. Bull World Health Organ 2015; 93(12):877-880.

12. Britton J. Death, disease, and tobacco. Lancet 2017; 389(10082):1861-1862.

13. Centers for Disease Control and Prevention (CDC). Smoking and tobacco use - fast facts and fact sheets. 2018. [cited 2018 May 15]. Available from: https:// www.cdc.gov/tobacco/data_statistics/fact_sheets/index.htm

14. Schotte K, Commar A, Blecher E, Prasad V. Global challenges in tobacco control. Salud pública de México 2017; 59:5-7.

Article submitted 13/06/2018

Approved 25/03/2019

Final version submitted 27/03/2019 